\title{
ANALISIS BENTUK KOMUNIKASI DALAM PEMANFAATAN SISTEM INFORMASI KALENDER TANAM TERPADU DI KEMENTERIAN PERTANIAN
}

\section{ANALYSIS OF COMMUNICATION FORM IN THE USE OF INTEGRATED CROPPING CALENDAR INFORMATION SYSTEM IN THE INDONESIAN MINISTRY OF AGRICULTURE}

\author{
Abdul Aziz ${ }^{1}$, Pudji Muljono², Irsal Las ${ }^{3}$, Retno Sri Hartati Mulyandari ${ }^{4}$ \\ ${ }^{1}$ Sekretariat Badan Penelitian dan Pengembangan Pertanian, J1. Ragunan No. 29 Pasarminggu \\ ${ }^{2}$ Program Studi Komunikasi Pembangunan Pertanian dan Pedesaan, IPB, \\ J1. Kamper Kampus IPB Darmaga \\ ${ }^{3}$ Balai Besar Penelitian dan Pengembangan Sumberdaya Lahan Pertanian, \\ Jl. Tentara Pelajar No. 12 Cimanggu, Bogor \\ ${ }^{4}$ Pusat Perpustakaan dan Penyebaran Teknologi Pertanian, Jl. Juanda No. 20 Bogor \\ ayizhar@yahoo.com
}

Diterima : 09 November 2019

Direvisi : 31 Januari 2020

Disetujui : 16 Maret 2020

\begin{abstract}
Integrated Cropping Calendar Information System (ICCIS) is a tool to determine the start of the growing period, the use of varieties, ideal fertilization, information on pest attacks, and the use of tools and agricultural machinery in climate change adaptation. One of the problems faced in utilizing ICCIS is the lack of feedback from users. The purpose of this paper is to identify and analyze the forms of communication between parties in the implementation of ICCIS. A qualitative approach was taken to analyse data. Data were collected using interviews, observations, and FGDs. Interviews were conducted to relevant institutions, agriculture instructors, and farmers who had received information on ICCIS. Observations and FGDs were carried out to farmers and agriculture instructors. Qualitative data analysis was carried out interactively, directly and continuously until finished using a descriptive method. The results showed that there were four forms of communication used in conveying information on ICCIS to farmers, namely organizational communication, group communication, non-mass communication, and interpersonal communication.
\end{abstract}

Keywords: Forms Of Communication, Cropping Calendar, Information Systems

\begin{abstract}
ABSTRAK
Sistem Informasi Kalender Tanam Terpadu (SI Katam Terpadu) merupakan suatu alat bantu yang mempermudah pengguna dalam menentukan awal musim tanam, penggunaan varietas, pemupukan yang ideal, mendapatkan informasi serangan hama penyakit, dan penggunaan alat serta mesin pertanian dalam beradaptasi dengan perubahan iklim. Salah satu hambatan yang dihadapi dalam pemanfaatan SI Katam Terpadu adalah kurangnya umpan balik dari pengguna. Tujuan dari penelitian ini adalah untuk mengidentifikasi sekaligus menganalisis bentuk komunikasi dalam implementasi SI Katam Terpadu. Pendekatan kualitatif dipilih dalam melakukan analisis. Pengumpulan data dilakukan dengan menggunakan metode wawancara, observasi, dan FGD. Wawancara dilakukan kepada lembaga-lembaga terkait, PPL dan petani yang telah mendapatkan informasi SI Katam Terpadu. Observasi dan FGD dilakukan kepada petani dan PPL. Analisis data kualitatif dilakukan secara interaktif dan langsung serta terus menerus hingga selesai dengan metode deskriptif. Hasil penelitian menunjukkan bahwa terdapat empat bentuk komunikasi yang digunakan dalam menyampaikan informasi SI Katam Terpadu kepada petani, yaitu: komunikasi organisasi, komunikasi kelompok, komunikasi nirmassa, dan komunikasi antarpribadi.
\end{abstract}

Kata Kunci: Bentuk Komunikasi, Kalender Tanam, Sistem Informasi 


\section{PENDAHULUAN}

Komunikasi merupakan proses penyampaian informasi dari komunikator kepada komunikan dengan tujuan untuk mengubah perilaku komunikan (Rogers, 2003). Komunikasi merupakan salah satu unsur penting dalam organisasi, karena dengan berkomunikasi akan muncul pendapat dan ideide dari anggota organisasi yang sangat berguna bagi kelangsungan hidup organisasi (Gautama, 2010). Demikian juga dalam sebuah lembaga penelitian, komunikasi merupakan hal yang penting dalam mencapai tujuan organisasi. Hasil-hasil penelitian harus dikomunikasikan kepada khalayak agar teknologi yang dihasilkan dapat bermanfaat bagi masyarakat.

Badan Penelitian dan Pengembangan Pertanian (Balitbangtan) yang mempunyai mandat melakukan penelitian di bidang pertanian dituntut untuk menciptakan inovasi baru dalam adaptasi perubahan iklim. Terobosan yang dilakukan Balitbangtan dalam hal ini adalah dengan membuat sistem informasi kalender tanam terpadu (SI Katam Terpadu). SI Katam Terpadu merupakan alat bantu yang mempermudah pengguna dalam menentukan awal musim tanam, penggunaan varietas, pemupukan yang ideal, informasi serangan hama penyakit, dan penggunaan alat serta mesin pertanian (Haryono, 2013). SI Katam Terpadu mampu menginformasikan kondisi musim tanam ke depan, yang meliputi awal waktu tanam, wilayah rawan banjir, kekeringan, organisme pengganggu tanaman (OPT), rekomendasi teknologi berupa varietas, benih, dan pemupukan berimbang (Runtunuwu et al., 2013).

Informasi mengenai SI Katam Terpadu disampaikan oleh pihak yang berkepentingan melalui berbagai bentuk komunikasi.
Balitbangtan sebagai aktor utama dalam proses ini telah berupaya mengomunikasikan SI Katam Terpadu kepada pihak-pihak terkait secara berjenjang, mulai dari internal organisasi hingga kepada pengguna akhir yaitu petani. Penyebaran informasi SI Katam Terpadu di internal organisasi dilakukan melalui unit pelaksana teknis (UPT) lingkup Balitbangtan yang tersebar di seluruh provinsi. Adapun penyebaran informasi mengenai SI Katam Terpadu di eksternal Balitbangtan dilakukan oleh lembaga dan aktor lain, di antaranya Dinas Pertanian baik provinsi maupun kota/kabupaten, penyuluh pertanian lapang (PPL), dan petani.

Salah satu tantangan berat dalam mengomunikasikan SI Katam Terpadu adalah saat menyampaikan pesan tersebut kepada seluruh stakeholders dan saat informasi tersebut diterima oleh pihak-pihak terkait. Proses ini berkaitan erat dengan alur informasi yang sangat dinamis dalam suatu organisasi (Pace \& Faules, 2000). Salah satu hambatan proses komunikasi dalam implementasi SI Katam Terpadu adalah kurangnya umpan balik dari petani (BB Pengkajian, 2016). Berkaitan dengan hal tersebut, tujuan dari penelitian ini adalah untuk mengidentifikasi sekaligus menganalisis bentuk komunikasi pihak-pihak terkait dalam implementasi SI Katam Terpadu.

\section{METODOLOGI PENELITIAN}

Penelitian ini dilakukan dengan pendekatan kualitatif. Pengumpulan data dilakukan dengan menggunakan metode wawancara, pengamatan langsung (observasi), dan diskusi kelompok terpumpun (FGD). Instrumen penelitian yang dipilih untuk mendapatkan data primer adalah wawancara. Adapun untuk memperdalam deskripsinya dilakukan observasi dan FGD. Wawancara 
dilakukan kepada lembaga terkait, PPL, dan petani yang sudah mendapatkan sosialisasi tentang SI Katam Terpadu, sedangkan observasi dan FGD dilakukan kepada petani dan PPL yang sudah mendapatkan sosialisasi SI Katam Terpadu. Lembaga yang dijadikan responden adalah Balai Penelitian Agroklimat dan Hidrologi (Balitklimat), yang merupakan penanggung jawab SI Katam Terpadu secara keseluruhan dan sekaligus sebagai Tim Katam Pusat, Tim Gugus Tugas Katam (TGT Katam) yang berada di setiap Balai Pengkajian Teknologi Pertanian (BPTP) di seluruh Indonesia, Dinas Pertanian provinsi, Dinas Pertanian kabupaten/kota, dan Balai Penyuluhan Pertanian (BPP). Adapun informan dari kalangan petani berasal dari ketua kelompok tani yang berjumlah enam orang. Wawancara bertujuan untuk mendapatkan gambaran yang jelas tentang proses komunikasi dalam pemanfaatan SI Katam Terpadu. Observasi dilakukan untuk mendapatkan pandangan petani terhadap SI Katam Terpadu, sedangkan FGD dilakukan untuk mendapatkan gambaran lengkap tentang alur informasi SI Katam Terpadu berdasarkan perspektif petani dan PPL.

Penelitian dilakukan di enam wilayah yang mewakili wilayah barat, tengah, dan timur Indonesia, serta Jawa. Penelitian di wilayah barat dilakukan di Sumatera Utara yang memiliki karakteristik iklim basah (Oldeman, et al. 1980). Di wilayah tengah, penelitian dilakukan di Kalimantan Selatan yang mempunyai karakteristik lahan rawa dan beriklim cukup basah (Noor, et al. 2016). Untuk wilayah timur, penelitian dilakukan di Nusa Tenggara Timur dan Nusa Tenggara Barat. Wilayah tersebut memiliki karakteristik lahan kering (Oldeman, et al. 1980; Djaenudin, et al. 2002; Mundita, 2013;
Assyakur \& Nurasa, 2010). Adapun penelitian untuk wilayah Jawa dilakukan di Jawa Barat dan Yogyakarta yang memiliki tipe lahan basah dan cukup basah (Wredaningrum \& Sudibyakto, 2014).

Penelitian kualitatif mencakup tahap konseptualisasi, kategorisasi, dan deskripsi yang dilakukan ketika kegiatan lapangan sedang berlangsung (Rijali, 2018). Analisis data dalam penelitian kualitatif dilakukan selama proses di lapangan yang bersamaan dengan kegiatan pengumpulan data (Sugiyono, 2010). Selain itu, analisis data kualitatif dapat dilakukan secara interaktif dan langsung secara terus menerus sampai selesai. Hasil FGD juga digunakan untuk mengembangkan deskripsi yang diperoleh dari survei dengan cara membandingkan hasil FGD dengan hasil survei.

\section{HASIL DAN PEMBAHASAN}

\section{Pelaksanaan Diseminasi SI Katam Terpadu}

Berdasarkan Permentan No.45/2011, selain penyiapan rekomendasi teknologi spesifik lokasi dan penyediaan benih sumber, Balitbangtan di tingkat pusat juga mempunyai tugas sebagai berikut: (a) menyediakan kalender dan pola tanam berdasarkan lokasi, dan (b) menyediakan informasi dan teknologi adaptasi dalam menghadapi perubahan iklim. Informasi tersebut diperoleh dari hasil penelitian dan kajian yang dilakukan oleh peneliti Balitbangtan, yang termasuk di dalamnya adalah Tim Katam Pusat. Balitbangtan secara struktural menginstruksikan kepada Tim Katam Pusat untuk melakukan kajian dan penelitian yang terkait dengan Katam dan Perubahan Iklim (PI). Hasil penelitian dan kajian tersebut kemudian dilaporkan kepada Kepala Balitbangtan untuk digunakan dalam 
menentukan kebijakan. Selain itu, Kepala Balitbangtan juga menginstruksikan kepada Tim Katam Pusat untuk menyosialisasikan SI Katam Terpadu kepada stakeholders terkait, yaitu unit kerja dan unit pelaksana teknis lingkup Balitbangtan, Tim Gugus Tugas Katam (TGT Katam), Dinas Pertanian terkait, penyuluh lapangan, dan petani.

Balitbangtan, sebagai penghasil inovasi

SI Katam Terpadu, melakukan upaya diseminasi melalui kegiatan sosialisasi baik secara offline maupun online. Sosialisasi online dilakukan dengan menggunakan internet dan media sosial, sedangkan sosialisasi offline dilakukan dengan melakukan pertemuan, workshop, bimbingan teknis, dan pelatihan kepada pemangku kepentingan dan pengguna akhir. Pada kasus SI Katam Terpadu, sosialisasi dilakukan untuk menyampaikan informasi SI Katam Terpadu kepada pemangku kebijakan serta masyarakat pertanian agar dapat memanfaatkan informasi tersebut dalam perencanaan pertanian (Runtunuwu et al., 2013). Sosialisasi inovasi SI Katam Terpadu dilakukan secara terstruktur dan berkesinambungan. Sosialisasi formal dilakukan oleh lembaga-lembaga negara yang berwenang sesuai ketentuan yang berlaku sebagai agen sosialisasi (Solihat, 2008). Upaya yang dilakukan oleh BPTP dalam mengomunikasikan SI Katam Terpadu adalah memberikan pengarahan dan instruksi kepada TGT Katam agar melakukan sosialisasi kepada stakeholders di daerah. Sosialisasi SI Katam Terpadu dilakukan secara intensif agar para pelaku usaha pertanian dapat mengadopsi teknologi tersebut. Sosialisasi SI Katam Terpadu kepada TGT Katam dilakukan kepada Dinas Pertanian baik di tingkat provinsi maupun kabupaten/kota, Balai Penyuluh Pertanian (BPP)/PPL, dan petani. Awalnya, sosialisasi SI Katam Terpadu di BPTP berjalan dengan baik dan lancar karena didukung oleh kebijakan pimpinan dan anggaran yang mencukupi. Namun, seiring dengan berubahnya kebijakan pimpinan dan sistem penganggaran, kegiatan sosialisasi SI Katam Terpadu secara formal rata-rata tidak dilanjutkan dan hanya berlangsung hingga tahun 2016. Hal ini disebabkan fokus kebijakan pimpinan yang lebih menitikberatkan pada program baru untuk keberhasilan swasembada pangan, seperti upaya khusus (upsus) dengan luas tambah tanam (LTT). Sebagai lembaga pemerintah di daerah yang membidangi pertanian, Dinas Pertanian tingkat provinsi berkoordinasi dengan BPTP juga melakukan sosialisasi kepada Dinas Pertanian tingkat kabupaten/kota dan BPP/PPL. Selanjutnya, Dinas Pertanian kabupaten/kota menyebarkan informasi inovasi SI Katam Terpadu kepada BPP/PPL dan petani. Sama halnya seperti Balitbangtan dan BPTP, kondisi di daerah juga mengikuti kondisi di pusat. Kegiatan sosialisasi SI Katam Terpadu pada mulanya berjalan dengan baik, namun setelah tidak ada lagi kegiatan SI Katam Terpadu di tingkat BPTP maka Dinas Pertanian provinsi dan kabupaten/kota juga tidak lagi melaksanakan sosialisasi SI Katam Terpadu kepada BPP/PPL maupun petani. Namun demikian, Dinas Pertanian kabupaten/kota dan BPTP terus mencari peluang dan strategi agar SI Katam Terpadu tetap tersampaikan kepada petani.

Strategi BPTP untuk tetap melakukan sosialisasi SI Katam Terpadu adalah dengan memanfaatkan momen kegiatan, baik yang dilaksanakan oleh BPTP sendiri maupun Dinas Pertanian/instansi terkait. Jika BPTP sedang melakukan kegiatan yang menghadirkan PPL dan petani, maka sosialisasi SI Katam Terpadu 
disisipkan di dalam kegiatan tersebut agar mereka sebagai pengguna dari teknologi tersebut mengetahui dan memahaminya. Demikian pula jika BPTP diundang oleh Dinas Pertanian/instansi lain, maka BPTP berusaha menyampaikan informasi SI Katam Terpadu dalam forum tersebut.

\section{Bentuk Komunikasi dalam Implementasi SI Katam Terpadu}

Komunikasi yang dilakukan di Balitbangtan sampai ke PPL dan petani dalam pemanfaatan SI Katam Terpadu adalah komunikasi secara top-down. Artinya, komunikasi dilakukan sesuai instruksi dari atas ke bawah, yaitu dari pimpinan tertinggi di pusat sampai ke tingkat penyuluh pertanian dan petani. Komunikasi seperti ini bersifat satu arah, artinya dalam komunikasi yang dilakukan belum ada umpan balik dari bawah. Komunikasi tersebut belum mempertimbangkan kebutuhan dari arus bawah. Alur komunikasi top down cenderung mempunyai pola komunikasi formal. Bentuk komunikasi seperti ini dilakukan secara prosedural dan berbentuk perintah yang harus dijalankan dan disampaikan kepada sasaran. Komunikasi formal dilakukan secara terstruktur, sistematis, lebih terfokus, efektif, dan jelas dengan tujuan untuk berkomunikasi (Sulaiman, 2013). Hasil wawancara dengan informan pada Dinas Pertanian kabupaten menyatakan bahwa:

“...penyebaran informasi SI Katam harus terstruktur, sistematis, dan masif (TSM), itu sudah otomatis, kalau ngga gitu ngga jalan. Kan...butuh produksi massal yang terpantau... kalau dilepas ya...harus terstruktur, sistematis, masif. Sentuhannya berapa persen ya harus TSM. Klo dilepas ya bisa puso..."
Berdasarkan hasil wawancara dengan Tim Katam Pusat diketahui bahwa penyampaian informasi SI Katam Terpadu dilakukan tiga kali dalam setahun, yaitu pada waktu musim tanam (MT)1, MT2, dan MT3. Informasi disampaikan secara berjenjang ke unit kerja dan unit pelaksana teknis (UPT) lingkup Balitbangtan dan kepada para PPL serta petani melalui kegiatan sosialisasi.

Komunikasi yang dilakukan dalam implementasi SI Katam Terpadu memiliki empat bentuk. Pertama, yaitu komunikasi organisasi yang dilakukan antarlembaga di lingkup Balitbangtan. Proses komunikasi dari Balitbangtan kepada Tim Katam Pusat, unit kerja (UK), UPT, dan lembaga di luar Balitbangtan dilakukan secara organisatoris. Kedua, komunikasi kelompok yang dilakukan oleh TGT Katam kepada PPL, Gabungan Kelompok Tani (Gapoktan), dan Kelompok Tani (Poktan). Kedua, komunikasi yang dilakukan oleh internal kelompok tani dalam menentukan awal musim tanam. Ketiga, yaitu komunikasi nirmassa yang dilakukan oleh TGT Katam kepada Dinas Pertanian di daerah. Keempat, adalah komunikasi antarpribadi yang dilakukan oleh penyuluh kepada petani secara informal.

Komunikasi yang dilakukan di Kementan berdampak pada pemanfaatan SI Katam Terpadu oleh petani. Hasil wawancara dengan petani yang sudah menerapkan SI Katam Terpadu menunjukkan bahwa SI Katam Terpadu mudah untuk diikuti dan memungkinkan petani mengetahui informasi tentang waktu tanam, pemilihan varietas, dan serangan organisme pengganggu tanaman (OPT) yang sesuai dengan kondisi di wilayah. Selain itu, penerapan SI Katam Terpadu juga terbukti dapat meningkatkan hasil pertanian 
petani. Hal ini sesuai dengan yang diungkapkan oleh petani pada waktu wawancara, yaitu:

“...aplikasinya mudah diikuti dan informasinya cocok, Pak... dengan adanya Katam kita bisa melihat Pak...bahwa di daerah mana saja yang sudah bisa melakukan tanam, kemudian supaya nanti pada saat panen kita tidak kebingungan dengan tenaga kerjanya. Kemudian varietasnya cocok Pak... kemudian serangan organisme pengganggu tanamannya bisa nampak di Katam..."

Selanjutnya, berkaitan dengan hasil produktivitasnya, petani tersebut menyatakan bahwa:

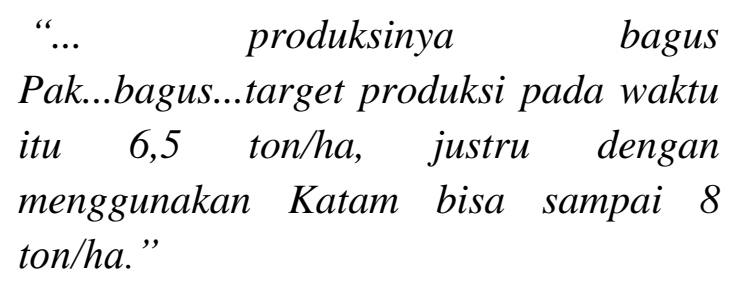

Namun demikian, sosialisasi yang dilakukan secara terstruktur, sistematis, dan masif tersebut masih belum membuat seluruh petani memanfaatkan SI Katam Terpadu karena sosialisasi belum dilaksanakan ke seluruh petani. Di samping itu, tidaklah mudah mengubah kebiasaan bercocok tanam petani yang selama ini dijalankan. Untuk menentukan waktu tanam misalnya, petani masih melihat volume curah hujan yang turun. Jika sawah sudah cukup tergenang air (macak-macak), petani baru mulai menanam padi. Selain itu, tersendatnya distribusi logistik seperti benih unggul dan pupuk bersubsidi juga dapat menyebabkan petani tidak mengikuti rekomendasi SI Katam Terpadu.

\section{Komunikasi Organisasi Implementasi SI Katam Terpadu}

dalam

Sebagai organisasi pemerintah yang memiliki tugas pokok dan fungsi di bidang penelitian, Balitbangtan bertugas menyampaikan hasil-hasil penelitiannya kepada stakeholders dan pengguna akhir. Komunikasi mengenai hasil penelitian tersebut dilakukan secara organisatoris kepada UK/UPT di bawahnya dan lembaga lain yang terkait secara berjenjang.

Dalam kasus perubahan iklim di Indonesia yang berpotensi memengaruhi sistem usaha tani, Balitbangtan membuat penelitian dan pengkajian terkait dengan adaptasi perubahan iklim. Hasil dari kajian tersebut adalah SI Katam Terpadu berbasis teknologi informasi, yang memudahkan penyuluh dan petani dalam menentukan awal musim tanam. Agar semua pihak yang berkepentingan dan pengguna akhir mengetahui hasil inovasi SI Katam Terpadu, maka Balitbangtan secara hierarkis mengomunikasikan dan menginstruksikan kepada unit kerja (UK) serta UPT lingkup Balitbangtan untuk meneruskan sosialisasi kepada stakeholders dan pengguna akhir. Hasil wawancara dengan Tim Katam Pusat menunjukkan bahwa penyampaian informasi SI Katam Terpadu dilakukan secara terstruktur dan berjenjang. Balitbangtan menginstruksikan kepada Tim Katam Pusat untuk membuat, memperbaiki, dan menginformasikan kepada seluruh UK/UPT lingkup Balitbangtan dan Direktorat Jenderal (Ditjen) serta Badan terkait mengenai SI Katam Terpadu. Tim Katam Pusat melakukan launching sekaligus sosialisasi SI Katam Terpadu kepada UK/UPT lingkup Balitbangtan dan Ditjen serta lembaga terkait, baik yang berada di internal maupun 
eksternal Kementan. Lembaga eksternal Kementan yang dimaksud adalah Badan Meteorologi, Klimatologi, dan Geofisika (BMKG) dan Badan Pusat Statistik (BPS).

Selanjutnya, setiap UK juga melakukan sosialisasi kepada UPT-nya masing-masing, termasuk juga BPTP yang melakukan koordinasi dengan pemerintah daerah. Balitbangtan juga membentuk TGT Katam Terpadu di setiap BPTP untuk melakukan sosialisasi, validasi, dan evaluasi SI Katam Terpadu di wilayahnya masing-masing.

Selanjutnya, TGT Katam Terpadu berkoordinasi dengan Dinas Pertanian provinsi menyampaikan informasi tentang SI Katam Terpadu kepada Dinas Pertanian kabupaten/kota. Selain itu, TGT Katam Terpadu juga menyampaikan informasi SI Katam Terpadu kepada BPP/PPL dan petani. Dinas Pertanian kabupaten/kota juga menyampaikan informasi SI Katam Terpadu kepada BPP/PPL, yang selanjutnya diteruskan para PPL kepada petani. Alur komunikasi organisasi dalam implementasi SI Katam Terpadu dapat dilihat pada Gambar 1.

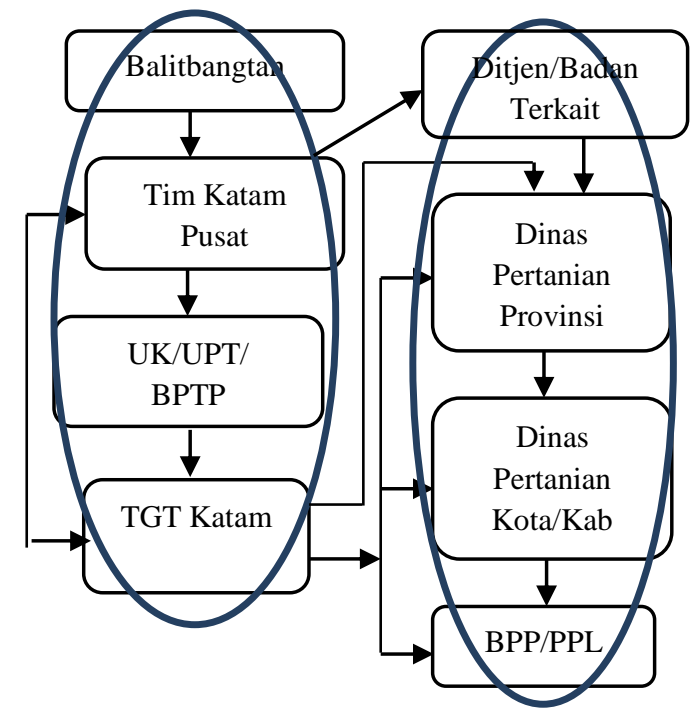

Gambar 1. Alur Komunikasi Organisasi dalam Implementasi SI Katam Terpadu
Gambar 1 menunjukkan bahwa Balitbangtan menginstruksikan kepada Tim Katam Pusat untuk melakukan sosialisasi kepada UK dan UPT (Balit dan BPTP). Instruksi dari Balitbangtan merupakan perintah dinas yang harus dilakukan secara terstruktur. Hasil wawancara dengan Dinas Pertanian kabupaten/kota juga menunjukkan bahwa dalam sosialisasi yang mereka lakukan kepada BPP/PPL, mereka maminta agar informasi SI Katam Terpadu disampaikan kepada para PPL dan petani di wilayahnya masing-masing secara terstruktur dan masif. Bentuk komunikasi organisasi yang dijalankan dari Balitbangtan sampai ke tingkat BPP bersifat top-down atau satu arah sehingga tidak memunculkan umpan balik yang maksimal dari internal organisasi. Hal ini sejalan dengan pernyataan Waskita (2005) yang mengemukakakn bahwa komunikasi dari atas ke bawah akan menghasilkan komunikasi yang bersifat satu arah.

\section{Komunikasi Kelompok \\ Implementasi SI Katam Terpadu}

Komunikasi kelompok merupakan bentuk komunikasi yang dilakukan oleh komunikator kepada sekelompok orang yang terdiri dari tiga orang atau lebih (Effendy, 2003). Kelompok merupakan bagian dari sistem yang lebih besar dalam kekuatan interaksi (Littlejohn \& Foss, 2009). Implementasi SI Katam Terpadu kepada pengguna juga dilakukan melalui komunikasi kelompok. TGT Katam Terpadu menyampaikan informasi SI Katam Terpadu kepada kelompok PPL, Gapoktan, dan Poktan. PPL merupakan kelompok tersendiri yang menerima informasi SI Katam Terpadu dari TGT Katam Terpadu. Kelompok Gapoktan dan Poktan merupakan kumpulan dari Ketua Gapoktan dan Ketua Kelompok Tani yang 
berada di suatu wilayah dan berjumlah cukup banyak sehingga menerima sosialisasi SI Katam Terpadu secara tersendiri. Selain itu, PPL juga menyampaikan informasi tersebut kepada kelompok tani di wilayah binaannya.

PPL yang sudah mendapat sosialisasi SI Katam Terpadu menyampaikan informasi tersebut kepada Gapoktan dan Poktan. Penyampaian informasi SI Katam Terpadu dilakukan pada pertemuan rutin yang telah dijadwalkan oleh Gapoktan maupun Poktan di wilayah binaannya masing-masing. Berdasarkan hasil wawancara dengan PPL dan petani, diketahui bahwa dalam sebulan minimal terdapat satu kali pertemuan dengan Poktan binaannya. Namun, dalam kondisi tertentu, pertemuan bisa dilakukan di luar jadwal yang ditetapkan. Jadi, dalam sebulan bisa diselenggarakan lebih dari satu kali pertemuan. Dalam pertemuan Poktan tersebut, PPL menjelaskan tentang SI Katam Terpadu yang kemudian dilanjutkan dengan diskusi sehingga terjadi komunikasi dua arah. Alur komunikasi kelompok dalam implementasi SI Katam Terpadu dapat dilihat pada Gambar 2.

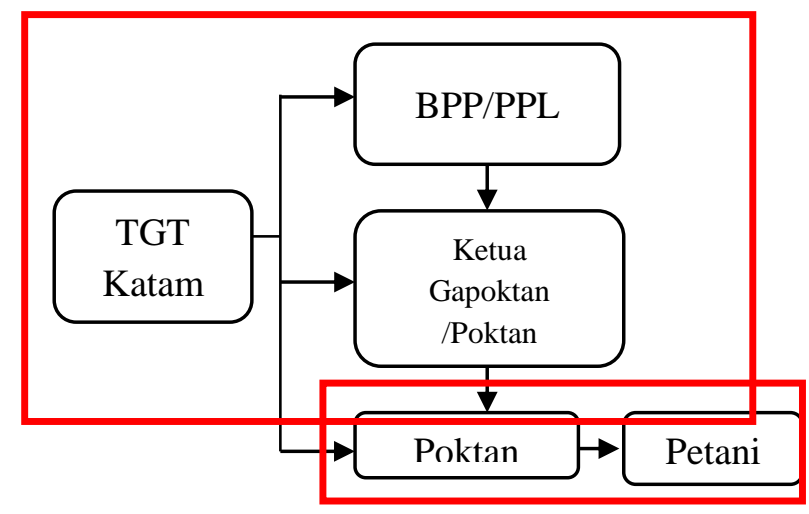

Gambar 2. Alur Komunikasi Kelompok dalam Implementasi SI Katam Terpadu

Gambar 2 menunjukkan bahwa Gapoktan juga menyampaikan informasi SI
Katam Terpadu kepada para anggotanya, yang terdiri dari beberapa Poktan di wilayahnya masing-masing. Sekalipun PPL sudah menyampaikan informasi kepada Gapoktan dan Poktan, keputusan implementasi SI Katam Terpadu diambil berdasarkan rapat dan kesepakatan setiap Poktan. Sebagai ilustrasi, hasil wawancara dengan ketua dan anggota Poktan menyatakan bahwa waktu tanam ditentukan melalui musyawarah dan ditetapkan berdasarkan kesepakatan bersama. Keputusan penggunaan rekomendasi yang lain seperti varietas, pupuk, serangan OPT, alat, dan mesin pertanian dilakukan dengan menyampaikan usulan Rencana Definitif Kelompok (RDK) dari Poktan kepada PPL. PPL kemudian melakukan rekapitulasi terhadap semua usulan dari Poktan dan mengajukan usulan tersebut melalui Rencana Definitif Kebutuhan Kelompok (RDKK) petani. Laporan RDK/RDKK yang sudah dibuat PPL kemudian disampaikan kepada Balai Penyuluh Kecamatan/BP3K dan dilanjutkan kepada BPP sebagai bahan informasi dan perencanaan pembinaan lebih lanjut.

\section{Komunikasi Nirmassa dalam Implementasi SI Katam Terpadu}

Komunikasi nirmassa merupakan bentuk komunikasi yang digunakan dalam menyampaikan informasi kepada kelompok atau beberapa orang yang terbatas, melalui media seperti surat, telepon, spanduk, pamflet, brosur, video, dan sejenisnya. Media nirmassa tidak memiliki keserempakan dan komunikasinya tidak bersifat massal (Effendy, 2002). Media nirmasssa sering digunakan pemerintah dalam upaya sosialisasi kepada masyarakat tentang program dan kegiatan yang telah ditetapkan (Komariah \& Subekti, 2016) Komunikasi nirmassa dalam 
implementasi SI Katam Terpadu dilakukan oleh TGT Katam kepada Dinas Pertanian provinsi. kabupaten/kota, BPP/PPL, dan petani. Alur komunikasi nirmassa tersebut tampak pada Gambar 3.

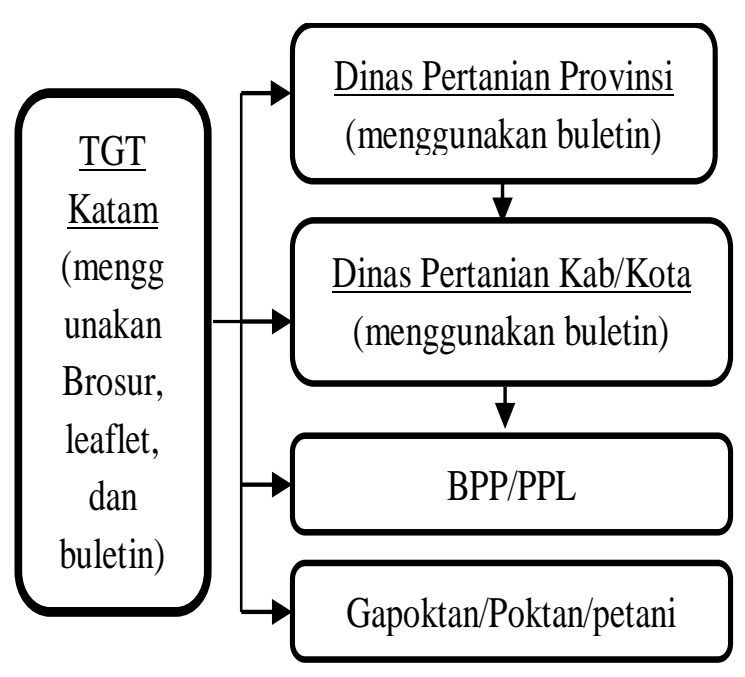

Gambar 3. Komunikasi Nirmassa dalam Implementasi SI Katam Terpadu

Komunikasi nirmassa pada Gambar 3 dilakukan dengan menggunakan leaflet, brosur, buletin, dan CD untuk penyebaran informasi yang dilakukan kepada beberapa orang dan kelompok. Komunikasi ini dilakukan oleh TGT Katam Terpadu pada saat pertemuan dengan Dinas Pertanian provinsi atau kabupaten/kota. Pertemuan tersebut dilakukan dengan mengundang para pegawai Dinas Pertanian provinsi/kabupaten/kota, BPP, PPL, Gapoktan, dan Poktan di setiap kabupaten/kota. Hal ini dilakukan untuk meningkatkan pemahaman kepada peserta pertemuan. Diharapkan dengan pencetakan leaflet, brosur, buletin dan CD sebanyak tiga kali dalam setahun, hal ini dapat semakin meningkatkan pemahaman peserta pertemuan terhadap SI Katam Terpadu secara visual. Penyebaran brosur, leaflet, $\mathrm{CD}$, dan buletin dilakukan pada saat musim tanam 1 (MT1),
MT2, dan MT3. Penyebaran media komunikasi nirmassa juga dilakukan TGT Katam Terpadu kepada BPP/PPL dan petani yang ikut hadir dalam pertemuan di Dinas Pertanian provinsi/kabupaten/kota dengan tujuan agar PPL dan petani dapat mengetahui teknologi SI Katam Terpadu sebagai adaptasi perubahan iklim di Indonesia. Dinas Pertanian provinsi bersama Dinas Pertanian kabupaten/kota menyebarkan informasi SI Katam Terpadu kepada BPP/PPL di wilayahnya masing-masing dengan menggunakan buletin yang dicetak tiga kali dalam satu tahun yaitu pada saat MT1, MT2, dan MT3. Hal ini dilakukan agar PPL lebih memahami dan menguasai materi tentang SI Katam Terpadu.

Kegiatan diseminasi SI Katam Terpadu kepada para petani dilakukan oleh TGT Katam dan para PPL secara pribadi. Sebagai penggerak pertanian di lapangan, PPL selalu berhubungan dengan petani untuk memberikan pengetahuan, pemahaman, penjelasan, dan informasi SI Katam Terpadu. Komunikasi antarpribadi dari TGT Katam dan PPL ke petani pada umumnya dilakukan secara informal. PPL bertemu petani saat sedang bekerja di sawah maupun sedang tidak bekerja, seperti saat berada di rumah atau bertemu di jalanan. Kondisi ini biasanya terjadi ketika PPL sedang mengawal dan mendampingi petani maupun saat menjalankan tugasnya dalam mengontrol kondisi persawahan petani yang menjadi wilayah tanggung jawabnya. Jika bertemu petani yang sedang berada di sawah, PPL menghampiri petani dan melakukan komunikasi tatap muka. Berdasarkan wawancara dengan petani, diketahui bahwa PPL dan petani bertemu di sawah sambil mendiskusikan permasalahan yang terjadi di lapangan. Mereka 
membicarakan perkembangan terbaru di bidang pertanian, seperti jenis varietas yang bagus, baik lokal maupun unggul. Namun demikian, informasi SI Katam Terpadu tidak luput disampaikan PPL kepada petani. Penyampaian informasi secara tatap muka ini diyakini PPL dapat lebih meyakinkan dan memengaruhi petani dalam mengimplementasikan semua teknologi, termasuk SI Katam Terpadu. Selain itu, komunikasi tatap muka ini dapat membuat petani lebih mudah memahami materi yang disampaikan oleh PPL.

Sementara itu, komunikasi antarpribadi yang dilakukan TGT Katam berlangsung saat petani menghubungi TGT Katam melalui alat komunikasi. Hasil wawancara dengan petani menyatakan bahwa terkadang petani menghubungi TGT Katam untuk mendapatkan solusi dalam mengatasi permasalahan di lapangan. Hal ini dilakukan jika PPL tidak dapat memberikan solusi karena keterbatasan dan kemampuan yang dimilikinya. Pada saat petani menghubungi TGT Katam melalui handphone, TGT Katam menyampaikan rekomendasi SI Katam Terpadu kepada petani. TGT Katam menjelaskan waktu tanam yang ideal, varietas yang cocok dibudidayakan, pemberian pupuk yang ideal, dan prediksi hama yang akan menyerang tanaman padi.

Selain itu, terkadang TGT Katam juga menghubungi Ketua Poktan atau petani yang sudah dikenal untuk menyampaikan rekomendasi SI Katam Terpadu menjelang waktu musim tanam tiba. Komunikasi antarpribadi dalam implementasi SI Katam Terpadu dapat dilihat pada Gambar 4 berikut ini.

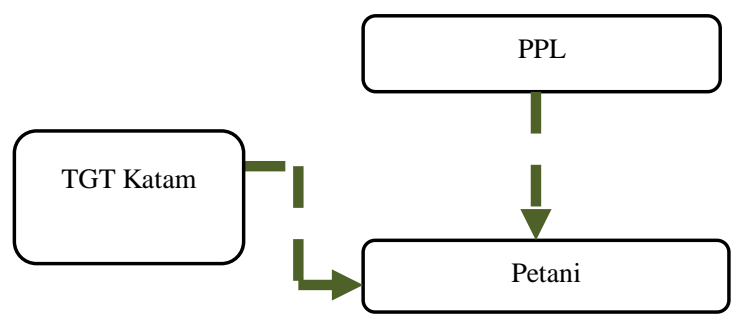

Gambar 4. Komunikasi Antarpribadi dalam Implementasi SI Katam Terpadu

Komunikasi antarpribadi dari PPL ke petani dinilai sudah cukup efektif karena sebagian besar petani sudah memahami kegunaan dari SI Katam Terpadu. Hasil wawancara dengan beberapa petani di lokasi penelitian menyatakan bahwa petani sudah mengetahui rekomendasi Katam Terpadu, bahkan sudah ada beberapa petani yang menerapkannya. Komunikasi antarpribadi akan lebih mudah membujuk komunikan karena adanya komunikasi lain dan pengaruh dari lingkungannya (Azhar, 2017). Komunikasi antarpribadi dalam implementasi SI Katam Terpadu dilakukan melalui tatap muka. Hal ini sesuai dengan kajian yang dilakukan BB Pengkajian (2016) dan Yulianti et al. (2016) yang menunjukkan bahwa petani lebih menghendaki komunikasi langsung secara tatap muka. Hal ini disebabkan bentuk komunikasi tersebut menunjukkan keakraban dan kekeluargaan antara PPL dengan petani.

Komunikasi berperan sangat penting dalam penelitian dan pengembangan pertanian. Hasil inovasi SI Katam Terpadu yang dikembangkan tidak akan bermanfaat dan tidak berhasil guna jika tidak dimanfaatkan oleh penggunanya, terutama PPL dan petani. Agar dapat dimanfaatkan oleh pengguna, maka inovasi SI Katam Terpadu tersebut perlu dikomunikasikan melalui alur informasi yang sudah ditentukan di Kementan. Alur proses 
penyebaran SI Katam Terpadu dapat dilihat pada Gambar 5.

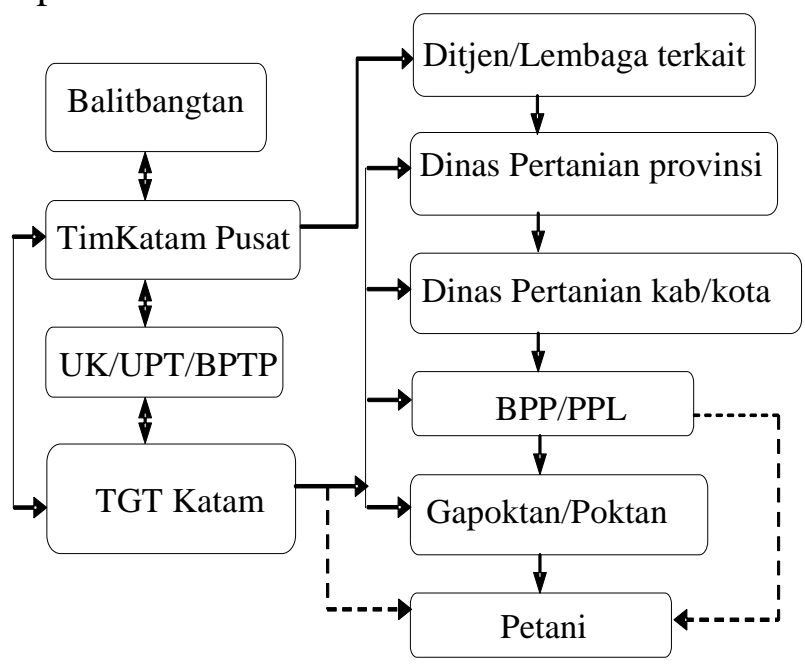

Gambar 5. Alur Proses Penyebaran SI Katam Terpadu

Alur komunikasi pada Gambar 5 menggambarkan proses penyampaian informasi SI Katam Terpadu secara struktural dan berjenjang. Balitbangtan sebagai penghasil inovasi SI Katam Terpadu membentuk dan menugaskan Tim Katam Pusat untuk menyampaikan SI Katam Pusat kepada seluruh UK/UPT di lingkup Balitbangtan, khususnya BPTP dan Direktorat Jenderal serta lembaga terkait di internal maupun eksternal Kementan. Selanjutnya, setiap BPTP yang dibantu oleh TGT Katam menyampaikannya kepada Dinas Pertanian provinsi/kabupaten/kota, BPP/PPL, Gapoktan, Poktan, dan petani. Dinas Pertanian provinsi juga menyampaikan informasi SI Katam Terpadu kepada Dinas Pertanian kabupaten/kota yang selanjutnya disampaikan kepada BPP dan PPL. Kemudian, PPL menyampaikan informasi SI Katam Terpadu kepada kelompok tani dan diteruskan kepada para anggota Poktan dan petani lainnya.

Penyampaian informasi SI Katam Terpadu dari Balitbangtan sampai ke tingkat PPL dilakukan secara formal dan hierarkis.
Proses komunikasi formal diawali dengan membuat surat instruksi untuk melakukan sosialisasi ke semua stakeholders. Namun demikian, penyampaian informasi SI Katam Terpadu dari TGT Katam dan PPL kepada petani dilakukan secara informal, yang ditandai dengan garis terputus pada Gambar 5. TGT Katam dan PPL mendatangi petani untuk melakukan sosialisasi SI Katam Terpadu.

\section{KESIMPULAN DAN SARAN}

Transfer teknologi SI Katam Terpadu kepada petani dilakukan melalui beberapa pihak. Pihak-pihak tersebut menyampaikan informasi SI Katam Terpadu melalui berbagai bentuk komunikasi. Bentuk komunikasi yang dilakukan dalam implementasi SI Katam Terpadu mencakup komunikasi organisasi, komunikasi kelompok, komunikasi nirmassa, dan komunikasi antarpribadi. Komunikasi organisasi dilakukan oleh instansi di internal Balitbangtan dan internal pemerintah daerah dari Dinas Pertanian provinsi sampai ke PPL. Komunikasi kelompok dilakukan oleh TGT Katam kepada PPL, Gapoktan, dan Poktan. Selain itu, komunikasi kelompok juga dilakukan oleh PPL kepada Gapoktan dan Poktan. Komunikasi nirmassa dilakukan oleh TGT Katam melalui brosur, leaflet, dan buletin kepada pegawai Dinas Pertanian baik di provinsi maupun kabupaten/kota, BPP/PPL, Gapoktan, dan Poktan/petani di seluruh kabupaten/kota. Komunikasi nirmassa juga dilakukan oleh Dinas Pertanian provinsi/kabupaten/kota kepada BPP/PPL melalui buletin yang dicetak pada saat MT1, MT2, dan MT3. Adapun komunikasi antarpribadi dilakukan oleh PPL dan TGT Katam kepada para petani.

Proses komunikasi yang terjadi dalam penyebaran informasi SI Katam Terpadu 
dilakukan melalui komunikasi formal dan informal. Alur komunikasi formal dilakukan secara berjenjang dari Balitbangtan sampai ke tingkat BPP/PPL, sedangkan alur komunikasi informal terjadi pada tingkat TGT Katam dan PPL yang menyampaikan SI Katam Terpadu ke petani.

Saran untuk penelitian lebih lanjut mengenai komunikasi yang efektif dalam implementasi SI Katam Terpadu yaitu dengan menambahkan objek penelitian berupa layanan survei kepuasan pelanggan dan layanan komunikasi dengan pakar pada aplikasi SI Katam Terpadu. Selain itu, sebaiknya dilakukan pula wawancara mendalam dengan pakar yang melakukan konsultasi pengguna secara teknis tentang pemanfaatan SI Katam Terpadu maupun interpretasi informasi yang disampaikan mengenai SI Katam Terpadu.

\section{DAFTAR PUSTAKA}

Assyakur, A.R., \& Nuarsa, I.W. (2010). Pemutakhiran Peta Agroklimat Klasifikasi Oldeman di Pulau Lombok dengan Aplikasi Sistem Informasi Geografi. Penelitian Masalah Lingkungan di Indonesia, halaman 7987.

Azhar. (2017). Komunikasi Antarpribadi: Suatu Kajian dalam Perspektif Komunikasi Islam. Jurnal Al-Hikmah, 9(14): 79-91.

BB Pengkajian. (2016). Laporan Tahunan Balai Besar Pengkajian dan Pengembangan Teknologi Pertanian Tahun 2016. Bogor: BB Pengkajian. Balai Besar Pengkajian dan Pengembangan Teknologi Pertanian.

Djaenudin, D., Sulaeman, Y., Abdurachman, A. (2002). Pendekatan Pewilayahan Komoditas Pertanian Menurut Pedo-
Agroklimat di Kawasan Timur Indonesia. Jurnal Litbang Pertanian, 21(1): 1-10.

Effendy, O.U. (2002). Dinamika Komunikasi. Bandung: Rosda Karya.

Effendy, O.U. (2003). Ilmu, Teori, dan Filsafat Komunikasi. Bandung: Citra Aditya Bakti.

Gautama, T.A. (2010). Peran Komunikasi dalam Organisasi. Jurnal Sosiologi Dilema, 25(2): 107-113.

Haryono. (2013). Kalender Tanam Terpadu: Generasi Baru Perencanaan Tanam Menghadapi Perubahan Iklim. dalam Kalender Tanam Terpadu. Dalam Haryono, M. Sarwani, I. Las, \& E. Passandaran (Eds.). Kalender Tanam Terpadu Penelitian, Pengkajian, Pengembangan, dan Penerapan (hal. 18). Jakarta: IAARD Press.

Komariah, K., Subekti P. (2016). Penggunaan Media Massa sebagai Agen Sosialisasi Dinas Kesehatan Kabupaten Tasikmalaya dalam Meningkatkan Kesadaran Masyarakat Akan Pentingnya Imuniasasi. PRofesi Humas, 1(1):12-21. Littlejohn, S.W., Foss, K.A. (2009). Teori Komunikasi. Hamdan MY, penerjemah. Jakarta: Salemba Humanika. Terjemahan dari: Theories of Humman Communication. Ed ke-9.

Mundita, I.W. (2013). Pemetaan Pangan Lokal di Pulau Sabu Raijua, Rote Ndao, Lembata, dan Daratan Timor Barat (Kab. Kupang \& TTS). Kupang: Perkumpulan Pikul.

Noor, R.A., Ruslan, M., Rusmayadi, G., Badaruddin. (2016). Pemanfaatan Data Satelit Tropical Rainfall Measuring Mission (TRMM) untuk Pemetaan Zona Agroklimat Oldeman di Kalimantan 
Selatan. EnviroScienteae, 12(3): 267281.

Oldeman, L.R., Las, I., Muladi. (1980). The Agroclimatic Maps of Kalimantan, Maluku, Irian Jaya, dan Bali. Bogor: West and East Nusa Tenggara Rest. Ins. Agric.

Pace, R.W., \& Faules, D.F. (2000). Komunikasi Organisasi: Strategi Meningkatkan Kinerja Perusahaan. Bandung: PT Remaja Rosdakarya.

Rijali, A. (2018). Analisis Data Kualitatif. Jurnal Alhadharah, 17(33): 81-95.

Rogers, E.M. (2003). Diffusion of Innovations. 5thed. New York: The Free express.

Runtunuwu, E., Syahbuddin, H., Ramadhani, F., Pramudia, A., Setyorini, D., Sari, K., Apriyana, Y., Susanti, E., \& Haryono. (2013). Inovasi Kelembagaan Sistem Informasi Kalender Tanam Terpadu mendukung Adaptasi Perubahan Iklim untuk Ketahanan Pangan Nasional. Pengembangan Inovasi Pertanian, 6(1): 44-52. Solihat, M. (2008). Komunikasi Massa dan Sosialisasi. Mediator, 9(1): 105-112.
Sugiyono. (2010). Metode Penelitian Kuantitatif, Kualitatif dan $\mathrm{R}$ \& $\mathrm{D}$. Bandung: Alfabeta.

Sulaiman, A.I. (2013). Model Komunikasi Formal dan Informal dalam Proses Kegiatan Pemberdayaan Masyarakat. Jurnal Penelitian Komunikasi, 16(2):173-188.

Waskita, D. (2005). Komunikasi Pembangunan untuk Pemberdayaan. Jurnal Organisasi dan Manajemen, 1(1): 32-40.

Wredaningrum, I., \& Sudibyakto. (2014). Analisis Perubahan Zona Agroklimat Daerah Istimewa Yogyakarta Ditinjau dari Klasifikasi Iklim Menurut Oldeman. Jurnal Bumi Indonesia, 3(4): 1-10.

Yulianti, A., Sirnawati, E., \& Ulpah, A. (2016). Introduction technology of Cropping Calendar-Information System (CC-IS) for rice farming as a climate change adaptation in Indonesia. International Journal on Advanced Science Engineering Information Technology, 6(1): 92-96. 
Jurnal PIKOM (Penelitian Komunikasi dan Pembangunan)

Vol. 21 No. 1 Juni 2020 